\title{
The Euro and the Euro Area: Flawed Construct or Unfit Members?*
}

\author{
Tamás Bánfi
}

The introduction of the euro was a political rather than an economic decision. Central banks opposed it, and European Union experts, including Sándor Lámfalussy, expressed their concerns that the harmonisation of the tax and fiscal policies leading to the economic union had not even been started, and Member States were reluctant to take even the initial steps. The establishment of the European Central Bank and the single monetary policy are necessary but not sufficient conditions for the operation of the euro area. The EU budget is inconsequential compared to the combined national budgets (one larger portion comprises the controversial agricultural subsidies), and it is unable to address the free movement of labour and capital within the integration or perform the necessary redistribution of income. Claiming that it is an optimum currency area does not hold water either. First, the political nature of the euro area dominates in the original formulation of the theory and also in today's focus, and second, in view of the present and its envisaged future, the euro area is based on the logic of geographical location. One question entailing profound consequences was not posed or answered during the introduction of the euro: what will happen if the individual economies of the members do not converge to the developed ones based on either real or nominal indicators, but rather diverge from them, and as a result the financing requirement of the balance of payments in certain countries steadily increases? No exchange rate adjustment can be performed, and the national government is unable or unwilling to reduce wage and income transfers, which would be an option for adjustment. Taking a look at the forced exchange rate adjustments in the more advanced European countries in the 30 years prior to the birth of the euro area, it should come as no surprise that after past and future enlargements of the euro area the real and nominal productivity developments of certain members exhibit divergence, the impact of which should be addressed.

Journal of Economic Literature (JEL) codes: E42, E52, F33, F45

Keywords: euro area, optimum currency area, euro, exchange rate

\footnotetext{
* The views expressed in this paper are those of the author(s) and do not necessarily reflect the offical view of the Magyar Nemzeti Bank.

Tamás Bánfi, Budapest Corvinus University, Emeritus Professor. E-mail: tamas.banfi@uni-corvinus.hu
}

The views expressed in this paper are those of the author and do not necessarily reflect the official view of the Magyar Nemzeti Bank.

The Hungarian manuscript was received on 2 October 2017.

DOI: http://doi.org/10.25201/FER.17.1.137152 


\section{Introduction}

In 1999, the euro area was established within the European Union. At the beginning of the first phase, it only affected banks, as bank money changed to the euro. In the second phase, from 2002, cash transactions started using the euro, which thus replaced the national currencies of members in all payments.

The introduction of the euro to supplant the national currencies in euro area countries was a simple process from a technical perspective. The exchange rate between the euro and the national currencies of the 11 founding countries was determined and fixed on 31 December 1998, based on which market prices, financial assets and liabilities and the monetary value of assets were converted into euros from 1 January 1999, i.e. the nominal values previously measured in national currencies were divided by the fixed euro exchange rates.

There is no precise method for determining the fixed euro exchange rates. One possibility is to base the calculation on the averages for the predetermined time range, and later country-specific adjustments may be performed taking into account the external and internal features of the national economy, but these are not necessary or compulsory. For want of a better formulation, nothing more can be stated than the fact that the conversion rates were realistic at the outset, and expressed the market share of the legacy currencies.

\section{Lámfalussy's view on the introduction of the euro}

Sándor Lámfalussy is often referred to as the father of the euro. This is unjustified, since he bears no responsibility for the introduction of the euro. That was a purely political decision, while experts, primarily national central bank representatives and also Lámfalussy, did not support the idea under the conditions in 1999.

Responding to a concrete question, Lámfalussy gave an answer succinctly outlining his professional stance: "It was a political mechanism. There never would have been a single currency if the decisions had been left to the central banks. Never. That's entirely clear. There was real interest in it among the governors, but it was principally those representing the smallest countries. The Belgians had that in mind... But Belgium is a small country. The Dutch certainly had doubts. They wanted to give themselves stability by tying themselves entirely to the Deutschmark. [...] On the French side, the Banque de France was entirely dependent on its government. It did not have a shred of independence. They would do whatever they were asked to do. Finally, the Germans did not want the single currency. The motivation was political, and the one man who played a very important role in persuading the people was Jacques Delors. [...] When Delors felt that one or the other of them and this was particularly true of Karl Otto Pöhl and his colleagues at the Deutsche 
Bundesbank - really did not want Monetary Union, he would explain the situation to Kohl. Kohl would then instruct Pöhl - irrespective of the independence of the Deutsche Bundesbank - to keep quiet. Once the governors had sensed that there was a political mandate, they remained essentially disciplined and participated in the establishment of the euro. They made a positive contribution, but they were not overjoyed about it..." (Lámfalussy - Maes - Péters, 2014, pp. 128-129).

Lámfalussy expressed his official expert opinion in a study entitled "Macrocoordination of fiscal policies in an economic and monetary union in Europe", and according to an interview on the study, "it stressed the weakness of the structures that were in the process of being created: we had a monetary pillar that was perfectly constructed, but no suitable economic pillar had been established. The problem of the policy mix stemmed from that. A policy mix involves both monetary policy and budgetary policy. The text explains why the coordination of budgetary policy is indispensable, and why an economic union needs to be created - i.e. a single budgetary and fiscal policy which acts as a counterpoint to monetary policy, allowing a combination of the two. So long as there is no coordination of fiscal policies, the outcome in terms of the overall fiscal impact is entirely uncertain. In fact, I compared the functioning of the EU with countries with federal structures, such as Germany, the United States and Switzerland, and I showed the percentage of public expenditure and public income that passed via the federal level and the percentage that remained in regional entities. It was clear that the federal level was the main element that the government was able to operate. By comparison, in the European structure, the percentage that passed via the Commission only accounted for around 1.5 or 2 per cent of GNP, and much of that related to the agricultural policy... The text was annexed to the report, and I'm fairly proud of it" (Lámfalussy - Maes - Péters, 2014, pp. 128-131).

In the end, the experts backed down in the face of political pressure. To the question whether the fact that experts failed to underline the necessity for an economic union in parallel with a monetary union was because they did not want to scare off politicians, thereby undermining the whole plan, Lámfalussy's answer was generally affirmative: "... we did say - and I've checked; I wrote this in my own note - that EMU would not be able to function without the coordination of fiscal and budgetary policies. Evidently, what was in the minds of some of us - myself included; I was no different - was that we hoped things would develop in that direction. That is to say, that once Monetary Union had been established, it would become increasingly clear that Monetary Union needed to be supplemented by an economic union. We hoped that there would be a move in that direction" (Lámfalussy-Maes - Péters, 2014, pp. 130-131). 


\section{Drawbacks of centralised monetary policies - Attempts at harmonising national fiscal policies}

Political decision-makers, principally at the convincing insistence of Jacques Delors, accepted that after the European single market is created, the single currency can be introduced if the European-level central bank pursues a single monetary policy. Experts' contrary opinion, for example the Lámfalussy study cited here, was not taken into account.

The birth of the euro area and the euro-harmonised monetary policy, as the interest rate policy of the European Central Bank, led to virtually the same interest rate levels across all members. Political and economic decision-makers assumed that the advantages emerging in the short run (reduction in transaction costs, elimination of exchange rate risk) would accelerate the convergence processes among members, that the Structural and Cohesion Funds would mitigate, and even eliminate in the longer run, the differences between the core and the periphery, and that the assumed positive effects arising from the operation of the single financial market would be beneficial irrespective of the business cycle. These expectations were highly exaggerated.

Both Hungarian and international literature analyse the consequences in detail and show how the assumptions were flawed. "Within the euro area, the euro is weak for the developed countries and strong for the group of southern countries, while the former group, in particular the German economy, is providing financing to the southern countries in the euro area. The crisis emerging in the euro area at various levels, for example the crisis of the welfare state and the internal crisis of the euro, has combined and become open in the southern Member States of the euro area, whereas it has remained hidden in the northern and western Member States, although it is starting to show in the growth and productivity data. [...] The euro area was designed for positive economic performance and was not prepared for crises. The introduction of the euro occurred between 1999 and 2001 during a period of exceptionally strong, simultaneous economic growth, and they were unable to devise an institutional system for the efficient functioning of the currency union and its ability to handle crises. This shortcoming is now evident, and it is the reason behind the continuous partially open, partially hidden crisis affecting the euro" (Matolcsy 2015, pp. 46-47). "In the European Union, the crisis was also influenced by the substantial differences in the inflation of the countries using the single currency in the years before the crisis, on account of the surplus inflation generated by the convergence processes and the increasing labour costs in certain countries. Inflation was substantially higher in Greece, Ireland and Portugal than, for example, in Germany. In the context of a common monetary policy and a uniformly low key interest rate, this made the real interest rate negative in the countries concerned, i.e. the countries were able to borrow and become indebted with a negative real 
interest rate. This was the main driver behind their growth, which ultimately led to the accumulation of significant amounts of debt and a considerable decline in competitiveness due to the lack of structural reforms" (Lehmann - Palotai - Virág (eds.) 2017, pp. 77-78). The significance of gross flows and stocks as compared to net balances should be underlined. The net external balance changes in line with the combined balance of the current account and the capital account, however, financing should be provided in line with gross developments, since the debt of one sector cannot be offset against the assets of another (Boros 2017, p. 88).

In contrast to the centralised monetary policy, national fiscal decisions remained practically at the national level. The introduction of the Stability and Growth Pact, which expected members to meet the figures determined for fiscal deficit and government debt in each cycle, can be attributed to either caution or a lack of confidence. The Pact's failure was indicated by the fact that in 2009, five Member States (United Kingdom, Greece, Ireland, Latvia and Spain) had a double-digit fiscal deficit. There were no sanctions, and there could not be any after the ECOFIN Council had voted against penalising Germany and France for their excessive deficits in 2003.

In the wake of the 2008 global financial crisis, the previously hidden shortcomings in budget management surfaced, therefore the reform of the Stability and Growth Pact became inevitable. In 2011, several regulations and Directive 2011/85/EU were adopted. The directive pertains to budgetary planning and management techniques and not to the Maastricht criteria, which may only be amended together with the Treaty (Pulay 2015). The criteria had to be made stricter without amending the Treaty, therefore first the so-called "six-pack" strengthened economic policy coordination, then the two-pack bolstered the supervisory powers within the euro area. The "six-pack", which considerably revised the Stability and Growth Pact, includes fiscal indicators as well as nine macroeconomic criteria. Failure to meet these or to take steps to improve them may be sanctioned. In 2012, 25 Member States signed an intergovernmental agreement called the "Treaty on Stability, Coordination and Governance in the Economic and Monetary Union" (Györffy 2013, Jankovics 2013).

The practice of fiscal oversight was tightened in the new system to facilitate prevention. The so-called "European Semester" was introduced, under which Member States have to submit their stability and convergence programmes by mid-April every year. Based on these, the Commission may conduct preliminary controls, make compulsory recommendations for the sake of coordination and consistency, and evaluate the steps governments have taken in response to the recommendations from the previous year. In addition to the clear-cut warnings, two quantifiable measures were introduced. The first compares the growth rate of the expenditure net of debt servicing, unemployment benefits and the EU subsidies flowing through the budget to the medium-term plans of the Commission. If Member States wish to introduce measures that increase the deficit, decisions 
offsetting this (by reducing expenditure or increasing revenues) must be made. The other benchmark refers to the gradual sinking of the portion of debt in excess of 60 per cent. These quantifiable obligations may be significant when it comes to the applicability of sanctions.

\section{The dilemma: Is the euro area a system that strengthens or at least does not weaken in the long run, or merely a short-term construct that exists due to political pressure?}

The lack of coordination between tax and fiscal policy leads to detrimental tax competition on the one hand, and impedes the redistribution facilitating social and economic convergence among participating countries on the other hand. Moreover, the "federal budget" is insignificant in size as compared to the combined amount of national budgets, and tax competition limits the volume of tax revenues and thus also budgetary spending despite greater needs. There is an undeniable need for a single fiscal policy in line with the single monetary policy. At the same time, it is unfathomable why no efforts were made to develop the corrective mechanism essential for smooth functioning, and why the members were not forced to avoid a change in the economic parameters determining the conversion coefficient between the national currency and the euro calculated at the birth of the euro area, or subsequently for later joiners, which reduces the external competitiveness of a country in the world market.

This condition may be easier to grasp from another perspective. The conversion cost of the currencies among each other notwithstanding, the introduction of a single currency and the following solution are equivalent: members keep their national currencies but the fluctuation band of the exchange rates among each other is zero, and the fixed exchange rates cannot be changed in the long run, essentially during the whole lifetime of the economic union. In this scenario, the condition for smooth functioning is the introduction of a single currency, there is basically no difference. But what can be expected in reality?

According to textbooks, exchange rates depend on interest rates in the short run, and on purchasing power parity through balance of payment positions in the longer run, i.e. these determine exchange rate developments. Short-term effects falling under the scope of exchange rate speculation can now be disregarded. In the longer run, economic developments differ across members in an economic union both in terms of direction and magnitude, while the exchange rates of the currencies among each other are fixed, they cannot be affected by changes; therefore certain currencies are overvalued, while others are undervalued. The overvaluation or undervaluation of members' currencies can be prevented by stability in real productivity, which fundamentally determines international competitiveness, and unchanged prices, or changes affecting countries to the same 
extent. If the conditions are not met, a smaller increase (or a greater reduction) in real productivity and/or a more substantial price increase (minor price decrease) overvalues participating countries' currencies, and conversely, a more robust increase (or a smaller fall) in real productivity and/or a lesser price increase (greater price decrease) undervalues participating countries' currencies. If a single currency was chosen and introduced in an economic union instead of keeping members' national currencies, the single currency becomes overvalued or undervalued relative to the conversion rate determined and employed at the outset.

However, the measures addressing the effects of the symmetrical changes vary widely, depending to some extent on the magnitude of the changes. In theory, adjustments are always possible; in practice, however, they may prove impossible due to political reasons. There is no intense pressure to intervene in the case of undervaluation, while in the case of overvaluation, the export-import and capital export-capital import imbalances may cause a rising current account deficit, which has to be financed. The growing current account deficit continuously raises both the cost and amount of financing, and its upper limit is the amount of loans that can be obtained. Intervention or, ultimately, the need for intervention call for a reduction in wages, income other than wages and public transfers in line with the extent of the overvaluation.

The application of the theory to the European Union and the euro area leads to two conclusions:

- The euro is the common payment instrument in the economic union. The single and common fiscal and monetary policy are linked to an EU-level balance of payments. Similar to the state budgets in the US, Germany or Switzerland, members may only collect local taxes to finance aims in their local interest; or

- Member States using the euro pursue a common monetary policy, while tax and fiscal policy remain largely at the national level, and the balance of payments is continuously settled at the expense of the common foreign reserves.

The first is viable even in the long run, while the second is not. A continuous transition may lead from the first to the second, where euro area countries gradually harmonise tax and fiscal policies in addition to the common monetary policy, and converge in terms of price developments using income policy instruments. If necessary, the balance of payments is supplemented from the common foreign reserves. If the transition is not a real "transition" because some members do not accept the harmonisation and fail to make the necessary domestic national economy decisions, the members concerned have to leave the euro area, or those who are still outside are denied access to the currency area. The result is a twospeed European Union. The first group comprises the economic union countries, while the second includes the other Member States. 
Prior to the introduction of the euro, why was the possibility of depreciation in certain Member States and appreciation in others and thus the continuous imbalances in the balance of payments not even discussed? This mistake is especially baffling in view of the period between the 1960s and 1999. It can be seen that in all three periods (the repeated depreciation and appreciation of national currencies at the end of the 1960s, the currency snake, the European Monetary System) exchange rates fluctuated substantially, and currencies had to be depreciated and appreciated repeatedly. According to one possible answer, experts forgot the balance of payments requirement, just like it was not included in the convergence criteria for Member States. The other is a perhaps even more absurd assumption. Politicians kept instructing the "independent" central banks, which engendered defiance in central bankers, who forgot a critical issue, the balance of payments requirement. None of those involved in these developments will ever admit this, therefore everyone is free to think whatever they choose.

\section{The optimum currency area theory and the euro area}

Economic literature clearly attributes the optimum currency area theory to Robert Mundell's 1961 study. Many people have "tampered" with the original theory since, supplementing and expanding it in various ways. Despite the fact Mundell did not join the discussion on fixed and flexible exchange rates, he based his thinking on it, as a currency area requires that its member countries (territorial units) fix the exchange rates between themselves or use a common currency. Somewhat contrary to the public perception, Mundell stressed the importance of the political goal rather than an economic one. The integrated financial (currency) system is mainly optimal from a political perspective, and the same cannot be proven from an economic viewpoint, if it can be interpreted at all.

The two dimensions must be differentiated when understanding the concept of the optimum currency area. The political and economic entity of a democracy comprising a federation of several states (a typical example is the US) where the single currency is backed by a uniform institutional system, a single monetary policy and the federal budget is fundamentally different, from an integration of independent national economies based on their geographical location. While maintaining national identity, independent financial policy has to be renounced, which can only be warranted by the short- and long-term economic interests of the individual nation states. ${ }^{1}$

One acceptable synthesis of the debates surrounding the theory on optimum currency areas is provided by the textbook "Economics", which is able to satisfy

${ }^{1}$ The most prominent of the wide range of studies on optimum currency areas are the works by McKinnon (1963), Kenen (1969), De Grauwe (2012), Krugman - Obstfeld (2003), and the different approaches and supplements are discussed in detail in Boros (2017). 
the widest range of interest in economics: Group of regions or countries with high labour mobility among them, or that may be subject to similar, simultaneous aggregate demand and supply shocks. Under such circumstances, no large exchange rate movements are necessary in rapid macroeconomic adjustment, therefore they can fix the exchange rates of their currencies or use a single currency (Samuelson - Nordhaus 2012, p. 608). ${ }^{2}$

The establishment of the euro area was a political decision, and the subsequent enlargements were influenced by politics, too. "The Six" forming the core are at the centre of continental Europe, while later joiners are peripheral countries with very different parameters compared to "the Six" and to each other, therefore the composition of the euro area was exclusively based on geographical location rather than the criteria defined in the optimum currency area theory. Of course, the euro area can be analysed to see whether it meets the criteria of optimum currency areas - it clearly does not - but mitigating the consequences arising from the differences across members is in the common interest. We should once again quote the textbook by Samuelson - Nordhaus (2012): "Perhaps the greatest advantages may be political integration and Western Europe's stability - the region has lived in peace for six decades after waging wars against itself during a large part of its written history" (p. 525). Europe may look somewhat more attractive from Europe than from the US, but the outside opinion could be more realistic and true, thus it should be accepted.

\section{Development of nominal and real productivity in euro area countries}

The national currencies of the founding members of the euro area and of the countries that joined later were linked to the euro by predetermined and mutually accepted coefficients. The established coefficients were presumably realistic, although there is no precise method for their calculation. There is only a basis, the exchange rates of the national currencies between each other in the case of the founders, and the market rate of the national currencies and the euro in the case of later joiners. In the period directly preceding the introduction of the euro, without knowing the official exchange rate, the market rate may move up or down or even "oscillate nervously" for speculative or hedging purposes, but the average level of a longer period (3-6 months) is a market reality which countries can and should deviate from. That said, the extent of this deviation is limited. A large divergence would be unwarranted and unjustifiable.

\footnotetext{
${ }^{2}$ This justification is similar to the explanation of the smooth functioning of the international financial system based on the gold standard before the First World War: the four countries generating the overwhelming majority of global flows (UK, US, Germany, France) were in the same phase of their business cycles, therefore their mutual goods and capital flows increased or decreased in harmony, and there were no substantial balances of cross-border payments (Ford 1965).
} 
After the accession, the economies of members function with unchanged or slowly changing conditions and effectiveness, and based on that the prices and wages converted into euros at the outset change continuously. It is reasonable to assume that the direction of the changes does not vary much across members, while their extent typically does; this affects the flow of goods and capital among the members and outside the euro area differently, while the euro expresses the original ratios. Even if there are no spectacular signs yet, some non-negligible data points should be considered. ${ }^{3}$

One well-known tension arises from the latent overvaluation of the economy in Greece, where the situation is much more severe than suggested by the data, and the circumstances may be similar in Spain, and possibly in Portugal and Italy as well. However, predictable and unpredictable events can cause much bigger tensions than currently observed. If, instead of a "two-speed Europe", all the Member States of the European Union are encouraged to introduce the euro, the coefficients can probably not be determined at the time of their accession at a level acceptable to the Member States, which would thus most probably exclude a future overvaluation of the economy. Furthermore, some Member States may even split up (Spain, Belgium, Italy). If that happens, and, for example, Catalonia secedes from Spain, the euro has to be adjusted not only for Catalonia but also for the "rest" of Spain.

Of course, without the achievement of economic integration (which is realistic based on our current knowledge), several national economic policy goals and instruments can cause tensions, which can be adjusted by eliminating the latent overvaluation. Without going into details, one only needs to mention the well-known anomaly that interest rate levels derived from the single monetary policy of the European Central Bank are largely the same, while inflation rates vary across countries.

\section{Conclusions}

At the time of their accession, euro area countries converted the prices, wages, income transfers and the whole stock of assets valued in the national currency to the euro, using a predetermined coefficient. As national economies function, the parameters determining the effectiveness of this functioning vary, and labour productivity and prices depending on market developments also fluctuate. The European Union's subsidy policy aims to foster changes in the direction of convergence more or less successfully. The achievement of the common goal may be hampered by insufficient subsidies, inappropriate use of funds and misguided economic policies that do not help convergence but cause the affected countries

\footnotetext{
${ }^{3}$ See the data series in the Eurostat database:

Real labour productivity per person: http://ec.europa.eu/eurostat/tgm/refreshTableAction.do?tab= table\&plugin=1\&pcode=tipsna70\&language=en,

Nominal labour productivity per person: http://ec.europa.eu/eurostat/tgm/table.do?tab=table\&init= $1 \&$ language=en \&pcode=tec00116\&plugin $=1$.
} 
to lag behind. This can be observed in lower labour productivity growth (or in a worse-case scenario, even a drop in labour productivity growth) as compared to more advanced national economies, which constrains the competitiveness of exporters and boosts that of importers. This entails a financing requirement for the balance of payments deficit, which signals the latent overvaluation of the euro. The overvaluation can be increased by a potential higher inflation rate than in other participating countries, which creates a need for intervention. In the absence of an adjustment tool, the only option is to cut the wages of public sector workers and the income transfers paid from the government budget, to which the private sector can only adjust with a lag and to a lesser extent.

The government's decisions are aligned with the four-year political terms, i.e. they avoid drastic interventions and postpone them as long as possible, which further undermines the external position of the participating countries and increases the extent of the necessary adjustment. The development, adoption and compulsory application of a mechanism independent from national governments is inevitable.

The adjustment tool and technique cannot change, there is no other option, however, instead of a voluntary approach, the EU can and should intervene with a regulation across the integration. Based on its review of members with growing external debt, the EU institution designated for this task would, at predetermined intervals, for example every five years, establish the implicit overvaluation of the common currency (the euro) and its extent. In line with the decision of the EU institution, the government would cut the wages, incomes and budgetary transfers with a coefficient below 1 , which expresses the overvaluation, using legal regulation. Although market forces reign supreme in the private sector, the minimum wage can be reduced there as well.

The forced intervention may cause disagreement among stakeholders, but more advanced Member States can expect less developed ones to converge gradually by using the subsidies financed from the tax revenues of net contributor countries appropriately.

\section{Looking back: The instability of the exchange rate regime in the decades before $1999^{4}$}

From 1967 to the introduction of the \pm 2.25 exchange rate band. After the Bretton Woods Agreement was signed, the parity adjustments accelerated from 1967, as on 18 November the pound sterling was devalued, for the second time, less than

\footnotetext{
${ }^{4}$ The thirty-year-old history of Western European currencies' exchange rates is nothing more than a warning sign. The genuine or feigned haste of the countries in the European Union to get into the euro area does not promise fewer exchange rate tensions than in the past. Expecting to eliminate the need for exchange rate adjustments for good by requiring countries to spend two years in an "ante-room" before accession is overly optimistic, or perhaps even naïve. No references will be included in this historical section, as the description of the events can be found in old economic dailies.
} 
necessary. The weakening of the pound was halted, but the process continued with the French franc. Similar to the pound, the currency crisis was caused by a decline in export competitiveness rather than by speculation. Monetary reserves diminished by USD 2.5 billion in a year, the exchange rate of the franc on the currency market nosedived, and as a last resort, the central bank raised the interest rate from 3.5 to 5 per cent. The franc stabilised, but soon another "bombshell" hit when the news of the Deutschmark's appreciation started spreading.

The Deutschmark was undervalued relative to other currencies, especially the US dollar, the pound sterling and the franc. The FRG's balance of payments surplus increased every year due to the surplus of the trade balance. On account of the balance of payments surplus, foreign reserves rose close to USD 10 billion in 1968, while the exchange rate was above parity and below the upper intervention point. Even the possibility of appreciating the Deutschmark was considered an attack on overvalued currencies. While the news on the devaluation of an overvalued currency entails heightened instability in the given currency and temporarily strengthens other overvalued currencies, news on the appreciation of an undervalued currency weakens all the undervalued currencies.

The franc experienced another crisis on news of the Deutschmark's appreciation. The franc was exchanged en masse in the fourth quarter of 1968. The exchange rate of the franc started to fall, the central bank raised the interest rate from 5 to 6 per cent, and foreign reserves were depleted at breakneck speed. The foreign exchange market was closed on 20 November 1968, and was reopened only five days later. The public was convinced that the franc would be devalued, however, the French government scrapped the idea for political reasons. The appropriate devaluation was opposed by several countries, primarily the US. The original parity remained, and the Group of Ten provided a loan of USD 2 billion to support the exchange rate. The government introduced administrative measures.

Despite being devalued, the pound sterling did not stabilise. Instead of improving, the trade balance of the UK showed an unprecedented deficit. On 20 November 1968, the foreign exchange markets in the UK were closed for three days. The currency turbulences abated by early 1969 .

On account of the French presidential elections, the franc's devaluation was considered once again, as a result of which speculative money turned towards the FRG. The Deutschmark's exchange rate was at the upper intervention point, the West German central bank's foreign reserves increased, and the appreciation of the D-Mark came into focus again. The pound sterling weakened on the news, its exchange rate against the Deutschmark sank to the lower intervention point. This is because the West German central bank was only willing to undertake a partial intervention, and maintained the limit only against commercial banks; the pound sterling's exchange rate against the Deutschmark breached the intervention point. 
With a surprise decision on 8 August 1969, the French government devalued the franc by 12.5 per cent. On the eve of the West German election, 25 September 1969, the foreign exchange markets were closed. Four days later, on 29 September, they were reopened, but the West German central bank did not intervene on the foreign exchange market. The exchange rate of the Deutschmark rose above the intervention point against all currencies, and the exchange rate was allowed to float freely. The temporary nature of the floating could be expected, as the West German government appreciated the Deutschmark by 8.5 per cent.

On 9 April 1971, France made a spectacular announcement, namely that it was not willing to pursue a lending or foreign exchange policy dependent on the international situation, therefore it did not deem it necessary to lower the interest rate from 6.5 per cent. The French tried to go their own way once again, and failed this time as well. The crisis was prevented by the announcement of the West German Institute for Economic Research, namely that the only way of limiting dollar inflows and reining in inflation was to introduce a floating exchange rate regime for the Deutschmark. Upon hearing the announcement, speculators launched an attack, converting liquid funds into Deutschmark. The Bundesbank bought almost USD 1 billion at the lower intervention point (DM 3.63). The next day, capital flows continued, and on 5 May, after the opening of the foreign exchange market in Frankfurt, the West German central bank was forced to convert over USD 1 billion, therefore the foreign exchange markets had to be closed. The British and the French central banks were still willing to exchange the USD, therefore their dollar reserves bloated significantly. The West German foreign exchange market could not be opened at unchanged parity.

After considering the different options, on 10 May 1971 the FRG government decided to open the foreign exchange markets but suspend central bank interventions, and allow the exchange rate of the Deutschmark to rise, i.e. to float. On the same day, the Deutschmark appreciated against the dollar by 4 per cent.

In August, the US announced the suspension of the gold conversion of the USD and the introduction of a 10-per cent import duty. Following the International Monetary Fund's approval, two exchange rates were introduced for the franc on 23 August. The fixed parity was left unchanged on the official market where official and traderelated foreign exchange transactions were conducted, while the exchange rate was allowed to fluctuate on the free market as guided by the forces of supply and demand. The Benelux countries formed a monetary bloc, floating the exchange rates of their currencies against the outside world.

The "currency snake". After the Western European measures, all the countries concerned, now including Japan, called for an agreement, but due to their different views they were only able to agree that the devaluation of the US dollar was an essential precondition for monetary settlement. This need was coupled with a serious 
demand, and it was satisfied on 19 December 1971: the dollar was devalued against the other currencies by 7.9 per cent. At the same time, the floating of the yen and the Deutschmark was abandoned, and the two currencies were appreciated by 7.66 and 4.61 per cent, respectively. The French maintained the double exchange rate, and had no fixed exchange rate for only one currency, the Canadian dollar. With the exception of these two currencies, the fixed-parity exchange rate regime was restored, but the prevailing \pm 0.75 -per cent floating range was increased to \pm 2.25 per cent. The devaluation of the dollar dispelled the myth that it was impossible to do so. However, the adoption of the \pm 2.25 -per cent range concerned particular interests. The broadening of this range violated the long-term goal of the European Economic Community, i.e. the achievement of the currency union, and also the prevailing system of settlements. The \pm 2.25 -per cent (4.5-per cent) band means that the exchange rates of all the currencies against the dollar should be kept within that range. In this system, with the exception of the dollar, the exchange rate between any two currencies could move in a 9-per cent range. For example if the Deutschmark is at the +2.25-per cent limit against the USD and the French franc is at the -2.25-per cent limit also against the USD, the position of the Deutschmark and the franc may change, with the Deutschmark sinking to the -2.25-per cent lower limit and the franc rising to the +2.25-per cent upper limit, thus the two currencies' exchange rates change by 9 per cent (4.5-4.5 per cent) relative to each other.

The 9-per cent fluctuation range was too broad for the members of the European Economic Community, therefore they decided to reduce the exchange rate fluctuation band between the currencies of the members to half that, i.e. 2.25 per cent ( \pm 1.125 per cent) from 24 April 1972, by harmonising foreign exchange market interventions. Thanks to that measure, the exchange rates of the EEC currencies could fluctuate within the \pm 2.25 -per cent band determined in December 1971, i.e. they could move up and down against the dollar as a group, by observing the allowed \pm 1.125 -per cent difference relative to each other. The Benelux countries maintained the larger range against other countries, while the band for the fluctuations against each other was called, figuratively, the "snake in the tunnel". If the limits of the fluctuation relative to each other are reduced to half of the figure for the outside world, the narrower band is called the neutrality point, and in this case the fluctuation bands against each other and against the dollar are the same.

The relative calm in 1972 was disrupted by the floating of the pound sterling in June. On 22 January 1973, Italy followed the French example, and the double foreign exchange market was introduced for the lira. In contrast to trading flows, the exchange rate of the lira was not protected in the case of capital flows, it developed in line with the current supply and demand. On 12 February 1973, a "bombshell" hit as the USD was devalued, for the second time in 14 months, by 10 per cent. After this, the finance ministers of the EEC decided to float the six strong currencies together against the dollar, i.e. to "let the snake out of the tunnel". The pound 
sterling, the Irish pound and the lira were left out of this. As a precaution, the Deutschmark was appreciated by 3 per cent.

The weakness of this combined float is that the extent by which the currencies in the Community can fluctuate relative to each other is limited, it cannot breach the upper and lower limit of the band, which, however, depends on the developments determining the position of the balance of payments. The inadequate adjustment of members may also prevent the float in bands. This is supported by the second appreciation of the Deutschmark by 5.5 per cent on 19 June 1973 in order to save the combined float, as well as by the French measure on 20 January 1974 when the franc left the "snake".

The European Monetary System. The internal exchange range rigidity of the currency snake required a new scheme, which, unsurprisingly, was established by the agreement between the German chancellor (Helmut Schmidt) and the French president (Valéry Giscard d'Estaing) on the predecessor to the euro area in March 1979. Beyond the general economic and social policy principles, the aim was to bind the currencies of the Member States closer together and to mitigate the overall exchange rate movements. The weighted basket of European currencies, the ECU, was developed. The ECU did not exist in the form of banknotes and coins, it was exclusively a unit of account.

The exchange rate of the ECU was determined by the weighted average of members' foreign exchange rates. The weights were determined based on trading flows within the Community and adjusted every five years. The initial proportions were modified twice until 31 December 1999. Members' currencies could deviate from the exchange rate expressed in ECU by \pm 2.25 per cent (with the exception of the Italian lira, for which 6 per cent was established. Tacitly, the Deutschmark dominated this set-up.

Summary. The conclusion summarising the practices of the past 30 years is evident. In the late 1960s and early 1970s, more advanced European countries were repeatedly forced to adjust their exchange rates. The currency snake used in the 1970s has proven that the narrower range of exchange rate movements introduced in order to achieve the currency union is too narrow and cannot be maintained for a long time in a system that excludes the possibility of currency parity adjustments. By changing the weighting of the currencies in the ECU basket, the European Monetary System sought to achieve the inevitable adjustment of currency parities, and these efforts were supported by members through continuous market interventions protecting exchange rates, and credit lines. In the 30 years before the introduction of the euro, the parity adjustments allowing exchange rate movements were necessary, and if they were constrained ("currency snake"), the system became unsustainable. Based on the experiences, there is no explanation for the optimistic assumptions in connection with the introduction of the euro. 


\section{References}

Boros, E. (2017): Endogenous Imbalances in a Single Currency Area. Financial and Economic Review 16(2): 86-116. http://doi.org/10.25201/FER.16.2.86118

De Grauwe, P. (2012): Economics of Monetary Union. Oxford University Press, Oxford.

Ford, A. G. (1965): The Truth About Gold. Lloyds Bank Review, 1965(7): 1-18.

Győrffy, D. (2013): A válság kezelés dilemmái Európában: a gazdaságpolitika depolitizálásának esélyei (Dilemmas of crisis management in Europe: The chances of depoliticising economic policy). In: Minden Egész eltörött. Akadémiai Kiadó, Budapest pp. 226-259.

Jankovics, L. (2013): A nemzeti gazdaságpolitikák mozgástere az új európai keretrendszerben (Room for manoeuvre of national economic policies in the new European framework). In: Minden Egész eltörött. Akadémia Kiadó Budapest, pp. 198-225.

Kenen, P.B. (1969): The Theory of Optimum Currency Areas: An Eclectic View. In: Mundell, R. Swoboda, A.: Monetary Problems of the International Economy. University Press of Chicago

Krugman, P. - Obstfeld, M. (2003): Nemzetközi gazdaságtan. Elmélet és gazdaságpolitika (International Economics: Theory and Policy). Panem Kiadó, Budapest

Lamfalussy, C. - Maes, I. - Peters, S. (2014): Az euro bölcse (The Wise Man of the Euro). Mathias Corvinus Collegium, Budapest

Lehmann, K. - Palotai, D. - Virág, B. (eds.) (2017): The Hungarian Way - Targeted Central Bank Policy. Magyar Nemzeti Bank, Budapest.

Matolcsy, Gy. (2015): Egyensúly és növekedés (Economic Balance and Growth). Magyar Nemzeti Bank, Budapest

McKinnon, P.I. (1963): Optimum Currency Areas. The American Economic Review, 53(4): 717-725.

Mundell, R.A. (1961): A Theory of Optimum Currency Areas. The American Economic Review, 51(4): 657-665.

Pulay, Gy. (2015): A költségvetési gazdálkodás és tervezés (költségvetési adótervezés) nemzetközi gyakorlata - az OECD költségvetési alapelvei, az EU költségvetési irányelvei, az EU kis tagállamainak költségvetési gazdálkodási gyakorlata (The international practice of budgetary management and planning [budgetary tax planning] - The OECD budgetary principles, the EU's budgetary policies and the budgetary management practices of small EU Member States). In: Adózási pénzügytan és államháztartási gazdálkodás Vol. II. Nemzetközi Közszolgálati Egyetem. Budapest, pp. 181-201.

Samuelson, P. A. - Nordhaus, W. D. (2012): Közgazdaságtan (Economics). Közgazdasági és Jogi Könyvkiadó, Budapest. 